\title{
MUTANT SUNFLOWER LINE R 12003, PRODUCED THROUGH in vitro MUTAGENESIS
}

\author{
Encheva, J., Shindrova, P., Encheva, V. and Valkova, D.
}

Dobroudja Agricultural Institute, General Toshevo 9520, Bulgaria

Received: March 15, 2012

Accepted: June 10, 2012

\section{SUMMARY}

Immature sunflower (Helianthus annuus L.) zygotic embryos of sunflower fertility restorer line R 2574 were treated with ultrasound before planting on the embryo culture medium. As a result some chlorophyll, leaf and inflorescence mutations were observed. New sunflower forms with inherited morphological, biochemical and phytopatological changes were obtained through selection and self-pollination. The line R 12003, subjected to investigation in this study, was characterized with significant changes concerning most of the studied characters. The contribution of the present research connected to the investigated mutation was the appearance of resistance to the parasite broomrape. The increased number of seeds per head in line R 12003, increased oil content in seed and $100 \%$ resistance to the parasite Orobanche are the desired combination in the breeding programme of sunflower.

Key words: Helianthus annuus, embryo rescue, ultrasound, mutant line, resistance (Plasmopara helianthi, Phomopsis helianthi, Phoma macdonaldii, Orobanche cumana)

\section{INTRODUCTION}

Improving plasticity and enriching genetic potential of sunflower can be realized through gene mutations and recombinations.

Among the other techniques used in modern breeding, the method of mutagenesis is considered as an effective one. Mutagenesis, both physical and chemical, proved favourable for mutation induction in tissue cultures. It is a technique which allows widening a heritable variability by inducing new traits. Some of them can be of interest as agronomically important characters; others can be used as marker traits.

Another promising technique is embryo culture (Plotnicov, 1983). The method allowed considerable shortening of the breeding process.

The mature seeds were subjected to mutagenic treatment more often (Jambhulkar et al., 1999; Sagadeesan et al., 2008). Lyakh et al., 2005 studied the frequency and spectrum of morphological mutations, raised in $\mathrm{M}_{2}$ after the treatment of mature and immature seed with ethylmethanesulphonate (EMS). 
Costov et al. (2007) increased resistance of tomato to Orobanche ramosa L. by application of EMS. Thirty-three types of chemical mutation at sunflower immature embryos were found, described and classified by Soroka and Lyakh, 2009. Encheva et al. (1993, 2002, 2003, 2008 and 2009) have reported statistically significant changes in morphological characters of plants regenerated from immature zygotic embryos of sunflower, independently and in combination with gamma irradiation or ultrasound. Encheva et al., 2008 and Encheva, 2009 created sunflower lines resistant to parasite broomrape after treatment of immature zygotic embryos with ultrasound.

Although sunflower breeding has been very successful throughout the last decades, a number of aims remain to be achieved, e.g., resistance to various diseases and the parasite Orobanche. However, these efforts are obviously limited by the narrow genetic base of commercial sunflower which has to be enlarged by the utilization of wild species, mutagenesis or tissue culture. Therefore development of new lines and hybrids resistant to diseases and to parasite broomrape is very important for sunflower breeding.

Broomrape is widespread in parts of Europe, Spain, the Near East and China (Škorić, 1994). According to Kaya et al. (2004), about $80 \%$ of the sunflower areas in Turkey (Trakia region) are infested with seeds of the parasite. Virulent races are overcoming the resistance of varieties and hybrids in Turkey, where the new races seem to be more virulent than the races present in other countries.

Broomrape also presents a serious problem to sunflower production in Bulgaria. Although a large number of Orobanche-resistant hybrids have been developed during the last years, there are still large areas infected with this parasite (Chindrova, 1994).

Downy mildew is a major disease in the regions with the mass production of sunflower. Currently the races of the pathogen with varying virulence are being observed.

Black (Phoma macdonaldi/Leptosphaeria lindquistii) and grey spots caused by Diaporthe/Phomopsis helianthi Munt.-Cvet. et al. are a serious problem for sunflower production in a number of countries worldwide (Škorić, 1994; Gulya, 1997; Carre, 1993), including Bulgaria (Encheva, and Shindrova, 1990).

Apart from chemicals and good agronomy practices recommended for control of diseases and broomrape on sunflower, the breeding method is the most efficient and economically most advantageous. The development of resistant lines, hybrids and their introduction in practice will lead to restricted propagation and distribution of the pathogens, and in the course of time, cleaning of the infected fields (Škorić, 1985; Vear and de Labrouhe, 1997; Hahn and Degener, 1999; Roustaee et al., 2000).

The aim of this study was: a) to develop variable initial breeding material from sunflower fertility restorer line R 2574 after treatment of immature zygotic embryos with ultrasound at dose $25.5 \mathrm{w} / \mathrm{cm}^{2}$ for $1 \mathrm{~min}$. before planting it in the nutrition 
medium, and b) to evaluate the new line R 12003 morphologically, biochemically and for resistance to phoma, phomopsis, downy mildew and parasite broomrape.

\section{MATERIAL AND METHODS}

A part of the experiments were carried out under laboratory conditions, while others were carried out at the experimental field of Dobroudja Agricultural Institute-General Toshevo.

\section{Development of mutant lines}

The Bulgarian fertility restorer line R 2574, which is highly homozygotic, was used as donor material. The main requirement to the initial plant material used according to the methods of embryo culture in combination with ultrasound is to be genetically pure, i.e., homozygotic to the highest possible degree. Therefore, the control line R 2574 with very good morphological uniformity was chosen as initial material for induced mutagenesis.

Plants were grown in the field and were hand-pollinated. The isolated immature seeds (13-16 days old) were treated with ultrasound at dose $25.5 \mathrm{~W} / \mathrm{cm}^{2}$ for $1 \mathrm{~min}$. Immature seeds were sterilized under the following conditions: 1) $1 \mathrm{~min}$ in $95 \%$ ethanol; 2) 15 min in bleaching solution $(2.7 \% \mathrm{Cl})$; 3) followed rinsing in sterile distilled water several times. Immature zygotic embryos were aseptically isolated and placed on nutrition medium $M$ for further growing (Azpiroz et al.): 1/2 MS (Murashige and Skoog, 1962) macro salts, MS micro salts, B5 vitamins (Gamborg et al., 1968), $20 \mathrm{~g} / 1$ sucrose, $\mathrm{pH}-5.7$. The conditions for cultivation were: $25^{\circ} \mathrm{C}, 16 / 8$ $\mathrm{h}$ photoperiod for one week. The plants which formed roots were transferred to soil and were further grown and self-pollinated in a greenhouse.

\section{Biometric evaluation of control line R 2574 and line R 12003}

The biometric evaluation and biochemical analysis of the control genotype and the newly developed mutant line were made on 10 plants for each individual year, and included 16 main agronomic traits as oil in the seed, 1000 seed weight, plant height, internode length, leaf width, leaf length, number of leaves, petiole length, head diameter, stem diameter, number of branches, length of branches, seed per head, seed length, seed thickness and seed width.

1000 seed weight $(\mathrm{g})$ was determined on three samples of 50 seeds per head each. The control data were collected from plants of the original line R 2574 which was grown in the field together with mutagenic plants.

\section{Biochemical analysis}

To determine the oil content of air-dry seeds from the materials included in the study, Nuclear-magnetic resonance (Newport Instruments Ltd., 1972) was used. 


\section{Phytopatological evaluation}

The phytopathological evaluation of the control genotype R 2574 and the obtained line R 12003 was performed with regard to the local Orobanche population and the diseases phomopsis, phoma and downy mildew at the Sunflower Phytopathology Laboratory and infection fields of DAI - General Toshevo.

The evaluation for resistance to downy mildew and broomrape was done according to standard methodologies (Gulya et al., 1991; Panchenko, 1975). The phytopathological evaluation of lines was performed with regard to downy mildew Plasmopara halstedii (Farl.) Berlese \& de Toni-race 300, 700 and to the local Orobanche population (race A-F). In order to characterize the resistance to downy mildew, the method suggested by Gulya et al. (1991) was used. The evaluation of 50 plants from a line was carried out using standard methodology: $0 \%=\mathrm{S}$ (sensitive); $100 \%=\mathrm{R}$ (resistant).

Broomrape resistance was evaluated under greenhouse conditions according to Panchenko (1975), being slightly modified to the local conditions. Broomrape resistance was calculated as percentage of non-infected plants. The reaction of 50 plants from each line was recorded using the following scale: 0-100\%.

The evaluation for resistance to attacks of grey spots (Phomopsis helianthi) and black spots (Phoma macdonaldii) was performed in the filed and in artificial infection plots. The type and severity of the attack were read one week after mass flowering according to the following scales:

Type of grey spot attack:

0 - no symptoms;

1 - a necrotic lesion up to $5 \mathrm{~cm}$ in diameter;

2 - a necrotic lesion over $5 \mathrm{~cm}$ in diameter;

3 - several merged necrotic lesions on the stem;

4 - a stem broken at the place of infection.

Type of black spot attack:

0 - no symptoms;

1 - a necrotic lesion near the petiole;

2 - several necrotic lesions on the stem;

3 - the entire stem is covered with necrotic lesion or the stem is broken.

Attacking rate: what portion of the plant's stem is covered with lesions of the pathogen (1/3, 2/3 or 3/3) (Encheva and Kiryakov, 2000).

\section{Statistical analysis}

The check line R 2574 and developed mutant line R 12003 were analyzed statistically with regard to the agronomic traits such as oil in the seed, 1000 seed weight, plant height, internode length, leaf width, leaf length, number of leaves, petiole length, head diameter, stem diameter, number of branches, length of branches, seed per head, seed length, seed thickness and seed width. 
Analysis of the experimental data was made by the statistical package BIOSTAST 6.0.

\section{RESULTS AND DISCUSION}

Immature sunflower (Helianthus annuus L.) zygotic embryos of the sunflower fertility restorer line R 2574 were treated with ultrasound before planting on an embryo culture medium. In vitro mutagenesis was done with embryo culture method, which allowed isolation of embryos before terminating their development and their planting on nutrition medium to grow in vitro seedlings.

Mutation process included chlorophyll mutations (Table 1) as Xanthovirescens (Figure 1), Albovirescens (Figure 2), Viridomaculata and Xantha of necrotic type (Figure 3). Most of the Xanthovirescens and Albovirescens cotyledons were developed to green plants.

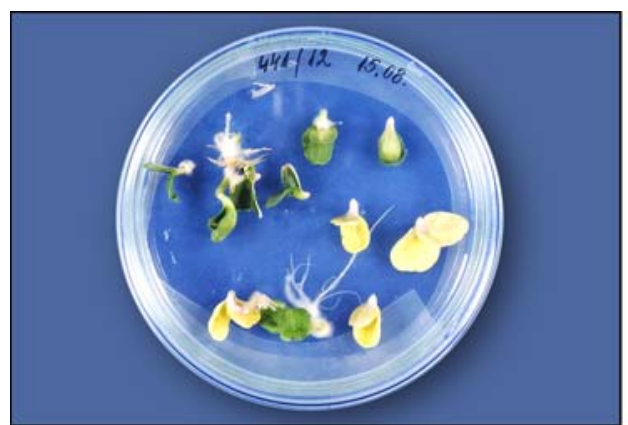

Figure 1: Chlorophyll mutation Xanthovirescens

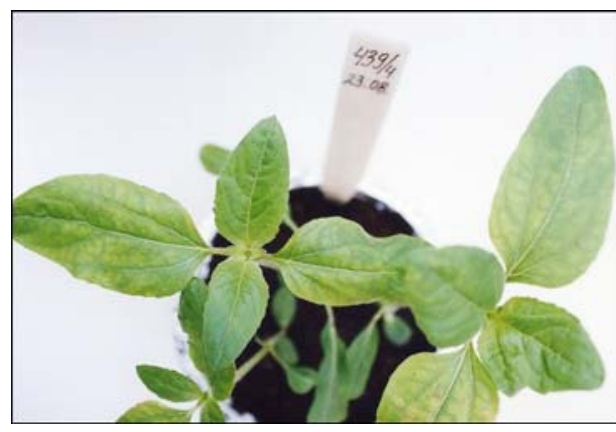

Figure 3: Sunflower mutant plants with chlorophyll types Viridomaculata and Xantha of necrotic type

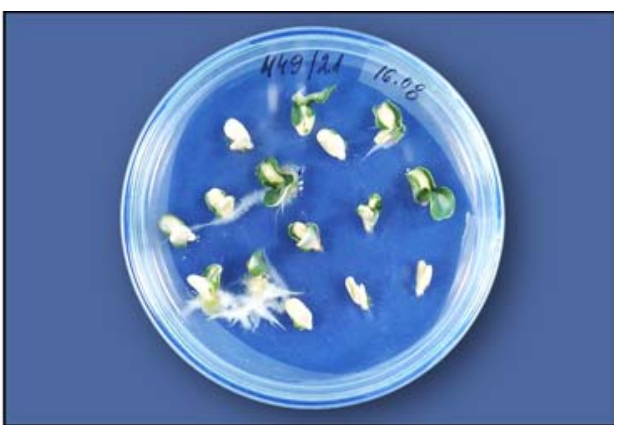

Figure 2: Numerous chlorophyll mutationsAlbovirescens

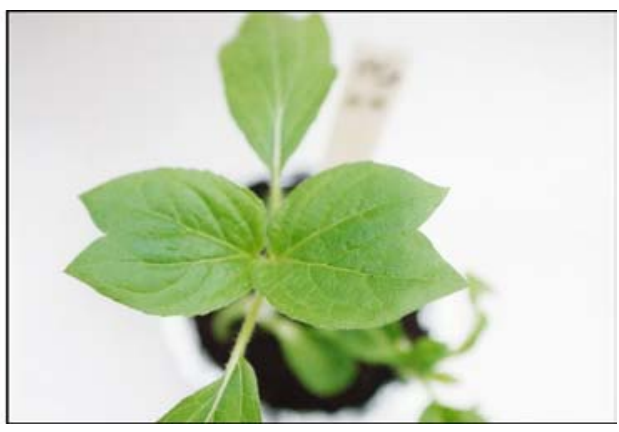

Figure 4: Leaf mutations (malformed leaf)

Another type of observed mutation was leaves without top or with double tops (Figure 4). We observed dwarf plants, full sterile plants, plants with decrease number of ray flowers, early flowering plants, malformed leaf, split leaf blades, fan- 
shaped venation, small and malformed capitulum, absence of ray florets, decreased number of ray florets and replacement of ray leaves with bract leaves. Some of these mutations were published by Soroka and Lyakh (2009) after treatment of immature zygotic embryo with EMS.

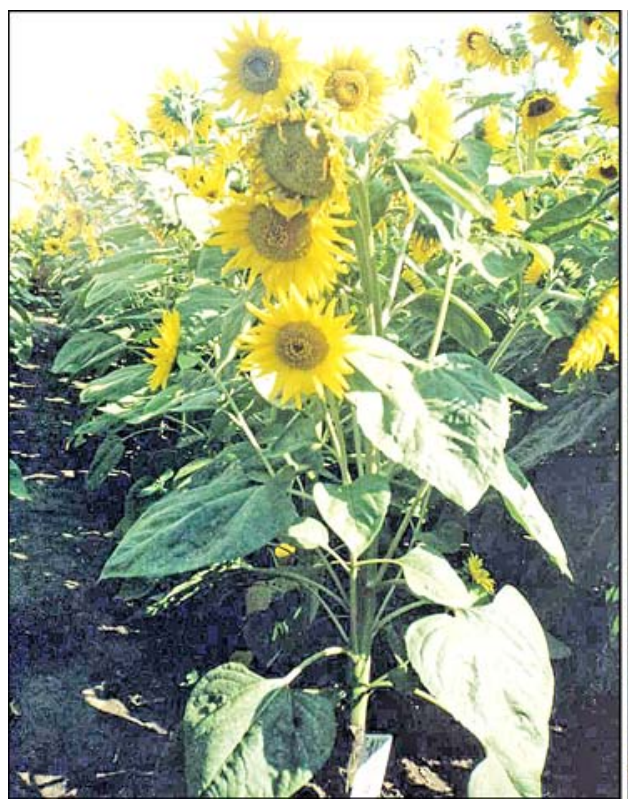

Figure 5: Standard line $2574 R$

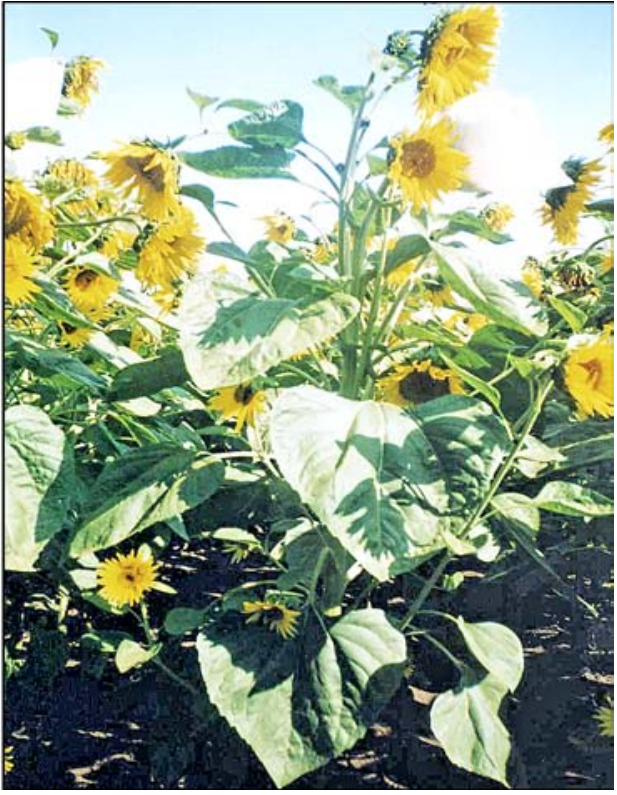

Figure 6: Mutant line 12003 R

Table 1: Type of morphological mutations in M1 and their descriptions

\begin{tabular}{|c|c|c|}
\hline $\mathrm{N}$ & Type of mutation & Characteristic \\
\hline & I Chlorophyll deficiency mutations & \\
\hline 1 & Xanthovirescens & Yellow-green cotyledons \\
\hline 2 & Albovirescens & White-green cotyledons \\
\hline 3 & Viridomaculata & Yellow-green leaves \\
\hline 4 & Xantha of necrotic type & $\begin{array}{l}\text { Yellow-green spots on the leaves, transforming } \\
\text { into necrotic segments }\end{array}$ \\
\hline & II Leaf mutations & \\
\hline 5 & Malformed leaf & Malformed, split leaf blades \\
\hline 6 & Dichotomous venation & Fan-shaped venation \\
\hline & III Steam mutations & \\
\hline 7 & Low-growing & Plant reduced in height \\
\hline & IV Inflorescence mutations & \\
\hline 8 & Malformed capitulum & Malformed \\
\hline 9 & Absence of ray florets & \\
\hline 10 & Few ray florets & Decrease number of ray florets \\
\hline 11 & $\begin{array}{l}\text { Replacement of ray leaves } \\
\text { with bract leaves }\end{array}$ & \\
\hline 12 & Small capitulum & Decreased size of capitulum \\
\hline 13 & Malformed capitulum & Inflorescence consisting of many malformed heads \\
\hline
\end{tabular}


In our study some mutant plants were isolated and self-pollinated for several generations. New sunflower forms with inherited morphological, biochemical and phytopathological changes were obtained through selection and self-pollination.

The line R 12003 (Figure 6) was preferred due to its significant differences with the control line R 2574 (Figure 5) resistance to phomopsis, phoma, downy mildew and broomrape and good combining ability.

Table 1 presents data on the significant change of the mean value for the character plant height. Plant height is one of the morphological indices most often investigated in cultural sunflower. It is considered a quantitatively inherited character. Increased plant height is controlled by dominant genetic effects (Putt, 1966), 57\% dominant effects and 30\% additive effects (Lay and Khan, 1985) and dominance to over dominance (Kovačik and Škaloud, 1990).

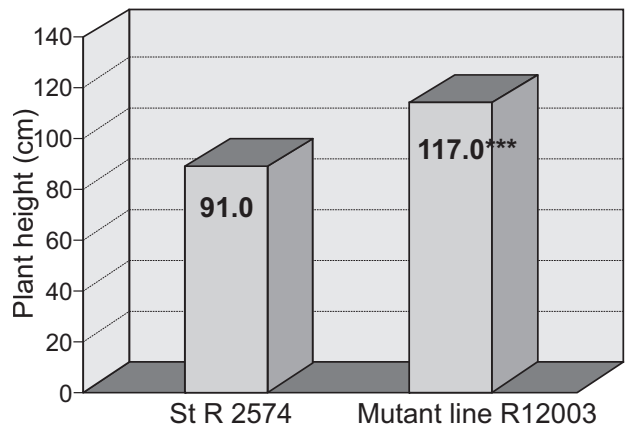

Figure 7: Plant height (cm) of control line $R$ 2574 and mutant line $R 12003$ $(* * *-P=0.1 \%)$

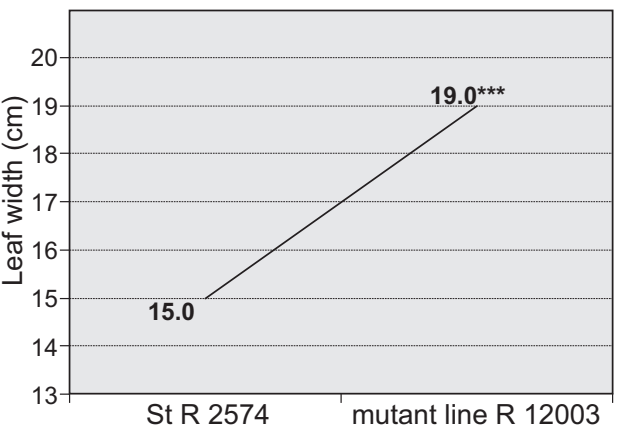

Figure 8: Leaf width $(\mathrm{cm})$ of standard line $R$ 2574 and mutant line $R 12003$ $(* * *-P=0.1 \%)$

The observed difference was considerable when their increase was taken into

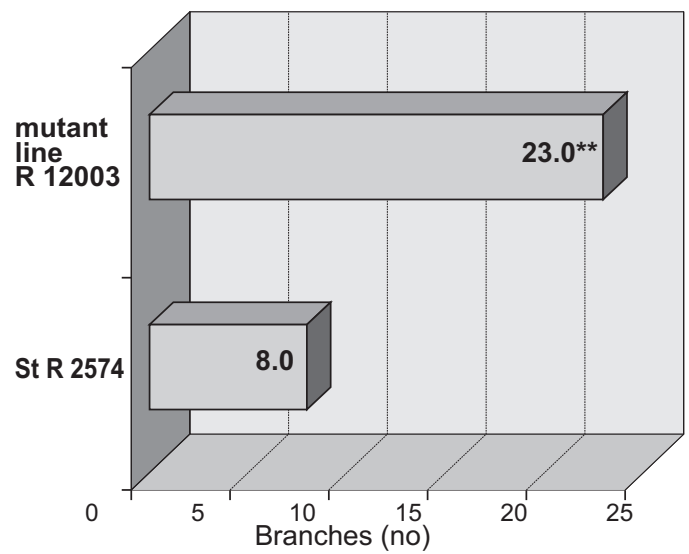

Figure 9: Number of branches of check line $R$ 2574 and mutant line $R 12003$. (**-P $=1 \%$ ) account. The new mutant line possessed plant height with $26.2 \mathrm{~cm}$ more than the control R 2574 (Figure 7 ). The difference was at the highest degree of significance. Vice versa decrease in plant height has been reported using the direct organogenesis method in combination with gamma irradiation (Encheva et al., 1993, 2002).

Novak et al. (1988) reported plant height reduction after treatment of immature zygotic embryos of maize with 5 Gy. Decrease in plant height of sunflower plants 
has also been observed by Hristov, 1996, after treatment of air dry seeds with gamma rays at doses 150 Gy and 200 Gy.

Larger photosynthetic surface at mutant line was possessed through considerable and statistically significant increase in leaf width with $4 \mathrm{~cm}$ (Figure 8), leaf length with $2.5 \mathrm{~cm}$ (Table 2) and larger number of leaves (Table 2).

A significant increase of number of branches with 15 (Figure 9), plant height, leaves size and number of leaves leads to changes in plant architecture of mutant line R 12003.

Oil content in seed is one of the most important agronomic indices (Figure 10). The results from dispersion analysis demonstrated a significant increase with $2.0 \%$ at mutant line R 12003.

Number of seeds per head is one of the characters forming seed yield (Figure 11). In our study we observed the increase of mean value of seeds with 190 numbers in comparison to the check line. The increased oil content and seed yield of the mutant restorer line produced were valuable changes with significant importance for the sunflower breeding programme.
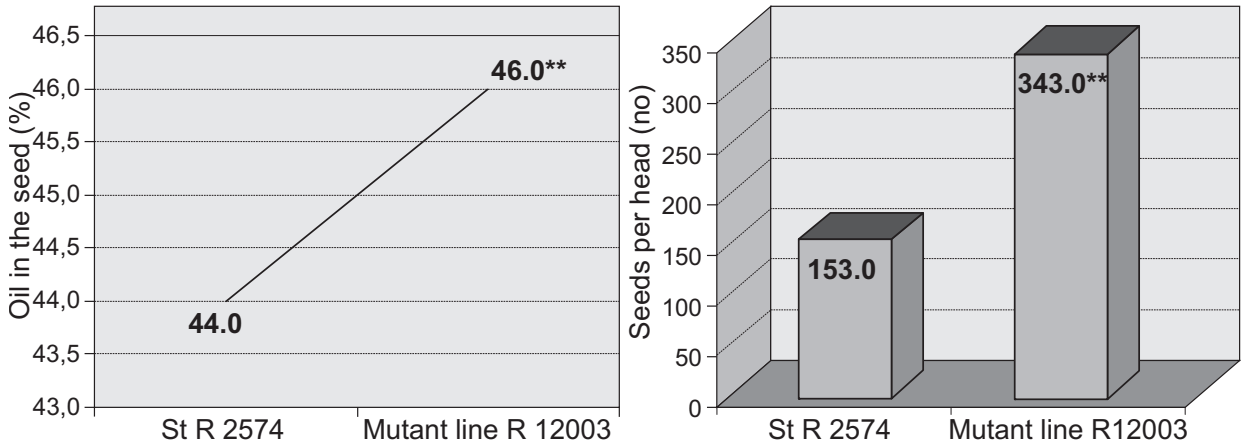

Figure 10:Oil in the seed (\%) of control line R Figure 11:Seeds per head (no) of control line 2574 and mutant line $R 12003$ (**-P=1\%) $R 2574$ and mutant line $R 12003$ (**-P=1\%)

Significant positive changes were noted for the characters internode length, stem diameter and head diameter. A maximum value of differences was $1.2 \mathrm{~cm}, 1.8$ $\mathrm{cm}$, and $1.3 \mathrm{~cm}$, respectively.

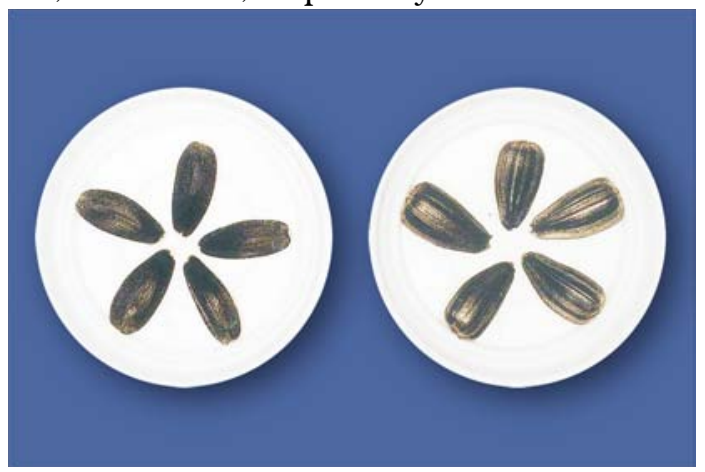

Figure 12:Seed size of control line $R$ 2574 (left) and mutant line R 12003 (right) 
The increase of $1.1 \mathrm{~mm}$ of the character seed length and the decrease of 0.5 $\mathrm{mm}$ (Table 2) at seed thickness leads to the change of seeds size of mutant line $\mathrm{R}$ 12003 (Figure 12).

Table 2: Significant morphological changes in the indices of line R 12003, developed from the control line R 2574. Averaged data

\begin{tabular}{lcccccc}
\hline \multirow{3}{*}{$\begin{array}{l}\text { Genotype } \\
2574 \mathrm{R}\end{array}$} & $\begin{array}{c}\text { Number } \\
\text { of leaves }\end{array}$ & $\begin{array}{c}\text { Leaf } \\
\text { length }\end{array}$ & $\begin{array}{c}\text { Petiole } \\
\text { length }\end{array}$ & $\begin{array}{c}\text { Seed length } \\
(\mathrm{mm})\end{array}$ & $\begin{array}{c}\text { Seed thick- } \\
\text { ness }(\mathrm{mm})\end{array}$ & $\begin{array}{c}\text { Seed } \\
\text { width }(\mathrm{mm})\end{array}$ \\
\cline { 2 - 7 } & Mean & Mean & Mean & Mean & Mean & Mean \\
& $(\mathrm{no})$ & $(\mathrm{cm})$ & $(\mathrm{cm})$ & $(\mathrm{mm})$ & $(\mathrm{mm})$ & $(\mathrm{mm})$ \\
\hline Control R 2574 & 21.00 & 16.23 & 10.73 & 9.98 & 3.62 & 4.86 \\
line R 12003- us & $24.00+\mathrm{c}$ & $18.77+\mathrm{c}$ & $12.13+\mathrm{b}$ & $11.10+\mathrm{b}$ & $3.14-\mathrm{a}$ & 4.92 \\
\hline
\end{tabular}

$\mathrm{a}, \mathrm{b}$ and $\mathrm{c}=$ significant of differences at the level of $0.05,0.01$ and 0.001 , respectively

Based on all 16 agronomic characters investigated, it can be determined that the positive significant differences were registered for plant height, number of leaves, leaf width, leaf length, petiole length, internode length, number of branches, stem diameter, head diameter, number of seeds per head, oil content in seed and seed length. This account for $75 \%$ of all characters studied. Vice versa, the negative change was registered for seed thickness, i.e., 6.3\% of the total number of traits. Stability after treatment of immature zygotic embryos with ultrasound was demonstrated by the character length of branches, seed width and 1000 seed weight.

\section{Evaluation of line R 12003 for resistance to some economically important diseases and parasite on sunflower}

Resistance of the mutant line to the local population of the broomrape races AF distributed in Bulgaria was established. The control line R 2574 was susceptible to this parasite.

In Bulgaria where sunflower is grown commercially, the successful production is endangered by many fungal pathogens and parasites. Losses may be severe, near $100 \%$ in parts or even entire fields under extreme circumstances. Because of the narrowed germplasm of cultivated sunflower, mutagenesis is applied as an alternative method of conventional ones.

In the nature the polyploid perennial species are considered as sources of resistance. Among them, $H$. tuberosus, $H$. scaberimus, $H$. divaricatus and $H$. rigidus have been most frequently used as a source of $100 \%$ resistance to Orobanche (Pustovoit, 1976). Studies of Christov, 1996 confirmed H. tuberosus as a source for Orobanche resistance, too. In Spain, Ruso et al. (1996) and Fernandez-Martinez et al. (2000) found resistance to several virulent races, including race F, in 29 perennial wild species. Fernandez-Martinez et al., 2008 reported the resistance to broomrape found in race $\mathrm{F}$ sunflower lines developed after cross-breeding with perennial wild species $H$. grosseserratus, $H$. maximiliani and $H$. divaricatus.

Burlov and Kostiuk (1976) and Pogorleckii and Gesele (1976) discovered that broomrape resistance was controlled by a dominant gene which was designated as Or. Many studies have showed a monogenic control by a single dominant gene over 
sunflower resistance against races A-E (Ish-Shalom et al., 1993; Sukno et al., 1999), although two dominant genes (Dominguez, 1996b) and one recessive gene (Ramaiah, 1987). The race $\mathrm{F}$ resistant population BR4, derived from wild species, was found to be under the control of a single dominant gene designated Or6 (PerezVich et al., 2002). Pacureanu et al. (2004) reported also a single dominant gene controlling the resistance to race $\mathrm{F}$ in Romania.

In our experiment we prove that $100 \%$ stable resistance of the sunflower mutant line to the local Orobanche population-race F can also be obtained through induced mutagenesis of cultured sunflower, by treatment of immature zygotic embryo with ultrasound, in particular. The same mutation, resistance to the parasite broomrape, was obtained in all variants of treatment of the initial genotype $\mathrm{R}$ 2574. Genetically, this regularity could be explained with existence of similarity of quantity of mutable genes in close relative organisms. The results allow us to presume that the resistance of the mutant sunflower line to Orobanche cumana occurred as a result from a single gene dominant mutation. Similar conclusion has been made by Christov et al., 1996, analyzing the type of resistance to broomrape of mutant sunflower forms obtained through irradiation of air dry seeds with gamma rays. The authors found out that it was controlled by a single dominant gene. The dominant resistant gene mutants were also obtained after EMS treatment of pollen of tomato (Gavazi et al., 1987).

The three years evaluation of line R 12003 showed immunity to Phoma macdonaldii, resistance to Plasmopara halstedii-race 300 and 700 and middle resistance to Phomopsis helianthi.

Although induced mutagenesis is a random and unpredictable process, it is an invaluable fact that the occurred mutation of resistance to the parasite broomrape is of stable inheritance in the progenies of the fertility restorer line.

\section{CONCLUSION}

As a result of treatment of immature zygotic embryos of the sunflower genotype R 2574 with ultra sound some chlorophyll, leaf and inflorescence mutations were observed. Owing to continuous self-pollination and selection, the line 12003 was obtained, which was distinguished by its morphological, biochemical and phytopathological differences.

The contribution of the present research connected to the investigated mutation was the appearance of resistance to the parasite broomrape. The studied line showed very good combining ability and it was included in the sunflower breeding program.

Having combined induced mutagenesis with embryo culture method, it was concluded that the new variability was exclusively due to the effect of the mutagen. This conclusion is confirmed by the fact that the embryo culture method alone does not generate variation, due to the lack of mutagen factors in the nutrition medium and a short period of in vitro cultivation of immature zygotic embryos. 


\section{REFERENCES}

Alonso, C., 1996. New highly virulent sunflower broomrape (Orobanche cumana Wallr.) phenotypes in Spain. Advances in parasitic plant research. $6^{\text {th }}$ International Parasitic weed Simposium. April 16-18, Cordoba, Spain.

Azpiroz, I.S., Vincourt, P., Serieys, H. and Gallais, A., 1988. La culture in vitro des embryous immatures dans l'acceleration du cycle de selection des lignees de tournesol et ses effects morphovegetatifs. Helia 10: 35-38.

Burlov, V.V. and Kostyuk, S.V., 1976. Breeding of restorer lines resistant to broomrape (Orobanche cumana) and downy mildew (Plasmopara helianthi). Proc. VII Inter. Sunfl. Conf., Krasnodar, SSSR, pp. 162-749.

Dominguez, J., 1996b. R-41, a sunflower restorer inbred line, carrying two genes for resistance against a highly virulent Spanish population of Orobanche cernua. Plant Breed 115: 203204.

Carre, M., 1993. Maladies du tournesol: le choix varietal avant tout. Cultivar 332: 46-51.

Christov, M., 1996. Characterization of wild Helianthus spices as sources of features for sunflower breeding. In: P.D.S. Calgari and D.J.N. Hind (eds). Composite: Biology and Utilization. Proceeding of the International Composite Conference, Kew, 1994. (D.J.N. Hind, Editor-in-Chief), Vol. 2: 547-570. Royal Botanical Gardens, Kew.

Encheva, V., and Shindrova, P., 1990. Observations on phomopsis severity in sunflower. Plant Growing Sciences 10: 24-27.

Encheva, J., Ivanov, P., Tsvetkova, F. and Nikolova, V., 1993. Development of a new initial breeding material in sunflower (Helianthus annuus L.) using direct organogenesis and somatic embryogenesis. Euphytica 68: 181-185.

Encheva, V., and Kirykov, I., 2000. A method for evaluation of sunflower resistance to Diaporthe/ Phomopsis helianthi Munt.- Cvet. Bulgarian Journal of Agricultural Science 8: 219-222.

Encheva, J., Tsvetkova, F. and Ivanov, P., 2002. Creating genetic variability in sunflower through the direct organogenesis method, independently and in combination with gamma irradiation. Helia 25(37): 85-92.

Encheva, J., Tsvetkova, F. and Ivanov, P., 2003. Comparison between somaclonal variation and induced mutagenesis in sunflower (Helianthus annuus L.). Helia 26(38): 91-98.

Encheva, J., Shindrova, P. and Penchev, E., 2008. Developing mutant sunflower lines (Helianthus annuus L.) through induced mutagenesis. Helia 31(48): 61-72.

Encheva, J., 2009. Creating sunflower (H. annuus L.) mutant lines using induced mutagenesis. B.J.A.S. 15(2): 109-118.

Fernandez-Martinez, J.M., Melero-Vara, J., Munoz-Ruz, J., Ruso, J. and Domingez, J., 2000. Selection of wild and cultivated sunflower for resistance to a new broomrape race that overcomes resistance of the Or5 gene. Crop Sciences 4(2): 550-555.

Fernandez-Martinez, J.M., Domingez, J., Perez-Vich, B. and Velasco, L., 2008. Update on breeding for resistance to sunflower broomrape. Helia 31(48): 73-84.

Gamborg, O.L., Miller, R.A. and Ojima, K., 1968. Nutrient requirements of suspension cultures of soybean root cells. Exp. Cell Res. 50: 151-158.

Gulya, T.J., Miler, J.F., Viranyi, F. and Sackston, W.E., 1991. Proposed internationally standardized method for race identification of Plasmopara halstedii. Helia 14: 11-20.

Gulya, T., 1997. Phomopsis stem cancer resistance in USDA and commercial sunflower germplasm. Proc. $19^{\text {th }}$ Res. Workshop, Fargo, 313-319.

Hahn, V. and Degener, J., 1999. Resistance of interspecific hybrids to Sclerotinia and Phomopsis in sunflower breeding. Helia 22(31): 173-177.

Jambhulkar, S.J., and Joshua, D.C., 1999. Induction of plant injury, chimera, chlorophyll and morphological mutations in sunflower using gamma rays. Helia 22(31): 63-74.

Sagadeesan, S., Kandasamy, G., Manivannan, N. and Muralidharan, V., 2008. Mean and variability studies in $\mathrm{M}_{1}$ and $\mathrm{M}_{2}$ generations of sunflower (H. annuus L.). Helia 31(49): 71-78.

Ish-Shalom-Gordon, N., Jacobsohn, R. and Cohen, Y., 1993. Inheritance of resistance to Orobanche cumana in sunflower. Phytopathol. 83: 1250-1252.

Kaya, Y., Demerci, M. and Evci, G., 2004. Sunflower (Helianthus annuus L.) breeding in Turkey for broomrape (Orobanche cernua Loefl.) and herbicide resistance. Helia 27(40): 199210 . 
Kostov, K., Batchvarova, R. and Slavov, S., 2007. Application of chemical mutagenesis to increase the resistance of tomato to Orobanche ramosa L. Bulgarian Journal of Agricultural Science 13: 505-513.

Kovačik, A. and Škaloud, V., 1990. Results of inheritance evaluation of agronomically important traits in sunflower. Helia 13: 41-46.

Lay, C.L. and Khan, S.F., 1985. Inheritance of plant height in six sunflower crosses. In: Proc. $11^{\text {th }}$ Sunflower Conf., Mar de Plata, Argentina, 10-13 March. Int. Sunflower Assoc., Toowoomba, Qld., Australia, 721-725.

Lyakh, V., Soroka, A. and Vasin, V., 2005. Influence of mature and immature sunflower seed treatment with ethylmetanesulphonate on mutation spectrum and frequency. Helia 28(43): 87-98.

Murashige, T. and Skoog, F., 1962. A revised medium for rapid growth and bioassays with tobacco tissues cultures. Plan. Physiol. 15: 473-497.

Newport Instrument Ltd., 1972. Use of the Newport quantity analyzer as a replacement for solvent extraction for measuring the oil and fat content of oil seeds, chocolate, meat and other materials. Newport Pagnell, England.

Pacureanu, M., Veronesi, C., Raranciuc, S. and Stanciu, D., 2004. Parasite-host plant interaction of Orobanche cumana Wallr. (Orobanche cernua Loefl.) with Helianthus annuus. In: Seiler, G.J. (Ed), Proc. 16 ${ }^{\text {th }}$ Int. Sunf. Conf., Fargo, ND, August 29-September 2, 2004. Int. Sunflower Assoc., Paris. pp. 171-177.

Panchenko, A.N., 1975. An early diagnostic method for resistance to Orobanche cumana Wallr. Agricultural newspaper. Nr. 2: 225-228 (in Russian).

Perez-Vich, B., Akhtouch, B., Munoz-Ruz, J., Fernandez-Martinez, J.M. and Jan, C.C., 2002. Inheritance of resistance to a highly virulent race " $F$ " of Orobanche cumana Wallr. in sunflower line derived from interspecific amphiploids. Helia 25: 137-144.

Pogorleckii, B.K., and Gesele, E.E., 1976. Resistance of sunflower to broomrape, downy mildew and rust. Proc. $7^{\text {th }}$ Int. Sunf. Conf., Krasnodar, SSSR. pp. 202-205.

Plotnicov, V.A., 1983. Use of method of culturing young embryos for accelerated development of sunflower cytoplasmic male sterility analogues. Cytology and Genetics 17(6): 42-46.

Pustovoit, G.V. and Krasnokutskaja, O.N., 1976. Wild Helianthus species as the results of sunflower for disease resistance. Proc. $7^{\text {th }}$ Int. Sunf. Conf., Krasnodar, SSSR, pp. 202205.

Putt, E.D., 1966. Heterosis, combining ability and predicted synthetics from a diallel cross in sunflower. Can. J. Pl. Sci. 43: 490-496.

Ramaiah, K.V., 1987. Control of Striga and Orobanche species. A review. In: Weber, H.C. and Forstreuter, W. (Eds). Parasitic Flowering Plants. Fhilipps-Universitat, Marburg, Germany, 637-664.

Roustaee, A., Costes, S., Dechamp-Guillaume, G. and Barrault, G., 2000. Phenotypic variability of Leptosphaeria lindquistii (anamorph: Phoma macdonaldii), a fungal pathogen of sunflower. Plant Pathology 49: 227-238.

Ruso, J., Sukno, S., Domingues-Gimenez, J., Melero-Vara, J.M. and Fernandez-Martinez, J.M., 1996. Screening of wild Helianthus species and derived lines for resistance to several populations of Orobanche cernua. Plant Disease 80(10): 1165-1169.

Soroka, A. and Lyakh, V., 2009. Genetic variability in sunflower after mutagen treatment of immature embryos of different ages. Helia 32(51): 33-46.

Škorić, D., 1985. Sunflower breeding for resistance to Diaporthe/Phomopsis helianthi Munt.Cvet. et al. Helia 8: 21-24.

Shindrova, P., Ivanov, P. and Nikolova, V., 1998. Effect of broomrape (Orobanche cumana Wallr.) intensity of attack on some morphological and biochemical indices of sunflower (Helianthus annuus L.). Helia 21(29): 55-62.

Shindrova, P., 2010. Investigation on the composition of downy mildew (Plasmopara halstedii Farl. Berlese et de Toni) in Bulgaria during 2007-2008. Helia 33(52): 19-24.

Škorić, D., 1994. Sunflower breeding for resistance to dominant diseases. EUCARPIA-“Section oil and protein crops". Albena (Bulgaria), 22-24 October. Pp. 28-30.

Sukno, S., Melero-Vara, J.M. and Fernandez-Martinez, J.M., 1999. Inheritance of resistance to Orobanche cumana Loefl. In sex sunflower lines. Crop Science 39: 674-678.

Vear, F., Garreyn, M. and Tourvieille de Labrouhe, D., 1997. Inheritance of resistance to Phomopsis (Diaporthe helianthi) in sunflower. Plant Breeding 116(3): 277-281. 